\title{
Taxonomic and Faunistic Results on the Spilomelinae Guenée, 1854 (Lepidoptera: Crambidae) from the Southern Arabian Peninsula with Descriptions of Three New Species
}

\author{
Michael Seizmair \\ Department of Entomology, Bavarian State Collection of Zoology Munich, Munich, Germany \\ Email address: \\ michael.seizmair@gmx.net \\ To cite this article: \\ Michael Seizmair. Taxonomic and Faunistic Results on the Spilomelinae Guenée, 1854 (Lepidoptera: Crambidae) from the Southern Arabian \\ Peninsula with Descriptions of Three New Species. American Journal of Entomology. Vol. 5, No. 1, 2021, pp. 1-9. \\ doi: $10.11648 /$ j.aje. 20210501.11
}

Received: December 13, 2020; Accepted: December 21, 2020; Published: January 4, 2021

\begin{abstract}
The Spilomelinae Guinée, 1854 (Lepidoptera: Crambidae) is known as the largest subfamily of the Pyraloidea with a wide distribution in the tropical and temperate zones. In the present study, new taxonomic and faunistic results on this subfamily are presented on the basis of material sampled in the south-western province Dhofar of Oman. In Dhofar three zoogeographical zones intersect, namely the Palearctic, Oriental and Afrotropical zones, with the Afrotropical fauna elements in the majority. The specimens of the sample are attributed to three species of three different genera, namely Herpetogramma, Lederer, $1883(\mathrm{n}=2)$, Notarcha, Meyrick, $1884(\mathrm{n}=2)$ and Glyphodes, Meyrick, $1884(\mathrm{n}=2)$ on the basis of external and genital-morphological characters. The specimens attributed to the genus Herpetogramma, Lederer, 1883 are assigned to a species group known as LBJ (Little Brown Jobs), the species of which are distinguishable by genital-morphological features exclusively. The specimens attributed to the genus Notarcha, Meyrick, 1884 revealed to be very close in wing pattern features to the Notarcha quaternalis Zeller, 1832 species complex. Comparison of the male genitalia of each of the sub-samples with the species of the respective sub-groups revealed significant differences, which result in the descriptions of the new species Herpetogramma debilis Seizmair, sp. nov. and Notarcha viridalis Seizmair, sp. nov. The presence of the genus Notarcha, Meyrick, 1884 is reported as new to the entomofauna of the Arabian Peninsula. The specimens attributed to the genus Glyphodes, Meyrick, 1884 differ significantly in external characters from a sample of seven species with similar forewing longitudinal line patterns. Among the species of this cluster Glyphodes onychinalis Guenée, 1854 is genital-morphologically very close to the specimens of the sample collected. The latter species and the specimens of the sample share the shape of the uncus and the structure of the corpus bursae wall, yet differ significantly in the structure of the valva. These differences result in the description of the new species Glyphodes leucomesalis Seizmair, sp.nov.
\end{abstract}

Keywords: Pyraloidea, Herpetogramma, Notarcha, Glyphodes, Taxonomy, Morphology

\section{Introduction}

The subfamily Spilomelinae Guenée, 1854 is known to be the subfamily with the highest diversity of the Pyraloidea, comprising 4097 described species in 338 genera and accounting for $26 \%$ of the species of the Pyraloidea $[1,2]$.

A recent comprehensive revision of the Spilomelinae Guenée, 1854 on tribus level has been done in Mally et al. [1]. Recent faunistic and morphological studies on species level have been done for the Indo-Australian, the Neotropical and the Afrotropical zones [3-6].
In the present study three new species attributed to three different genera, namely Herpetogramma, Lederer, 1883, Notarcha Meyrick, 1884, Glyphodes Guenée, 1854 are described on the basis of a sample $(n=6)$ collected by the author in Dhofar, the south-western province of Oman.

\subsection{Genus Herpetogramma, Lederer, 1883}

The genus comprises two species complexes. The members in each of these two species groups are primarily distinguished by genital-morphological characters. The two complexes are referenced as "group A" and "group B" by 
Guillermet $[7,8]$.

These two species groups are distinguished by the basic scaling of the fore- and hindwings - light-brown in the species of group A, darkish-brown in the species of group B. Group A is also referred to by the acronym LBJ (Little Brown Jobs) [9].

The species group B is widely distributed in the Palearctic, Afrotropical and the Indo-Australian zones $[2,10]$. On the contrary, the known species of group A are restricted in distribution to the Afrotropical zone, with records from islands of the Indian Ocean (La Reunion, the Comoros Islands, the Malagasy Region, the Seychelles Islands), from South Africa and from Namibia [7, 9, 11].

On the Arabian Peninsula, group B is represented by Herpetogramma licarsisalis Walker, 1859, whereas group A has not been recorded for the Arabian Peninsula up to now [12, 13]. In this study the presence of group $A$ is reported as new to the entomofauna of the Arabian Peninsula on the basis of a sample of two specimens. The specimens are assigned to a new species Herpetogramma debilis Seizmair sp.nov.

\subsection{Genus Notarcha, Meyrick, 1884}

This genus encompasses 18 known species and is distributed in the Afrotropical and Indo-Australian zones [1, 2, 13]. The genus is still little explored in the Afrotropical zone, with seven species known up to now and numerous unknown species conjectured $[11,13]$.

The distribution of the genus in the Afrotropical zone ranges over the Seychelles Islands, the Comoros Islands, the Malagasy Region, South Africa, Central and Eastern Africa to Ethiopia [13, 14].

The genus has not been recorded so far from the Arabian Peninsula [13]. In this study the presence of the genus on the Arabian Peninsula is reported for the first time on the basis of a sample of two specimens. The specimens are assigned to a new species Notarcha viridalis Seizmair, sp.nov.

\subsection{Genus Glyphodes, Meyrick, 1884}

This genus comprises 156 known species and is distributed in the Afrotropical, Neotropical and Indo-Australian zones [1, 2].

The genus is polyphyletic $[1,15]$. Sutrisno hypothesizes a subdivision of the genus into three monophyletic clades on the basis of morphological and molecular-genetic markers [15-18]. The phylogenetic results in Sutrisno are based on a sample of 14 species thus covering $9 \%$ of the total species of the genus. The subdivision of the genus proposed by Sutrisno should thus be regarded as preliminary. Further investigations into the phylogenetic relations between the species of the genus as a whole are needed.

Further recent studies on the morphology of the genus based on small species samples have been in done in Park et al., in Ratikannu and Chitra, in Nagaharish et al. and in Reddy and Murthy [19-22].

On the Arabian Peninsula, the genus is represented by Glyphodes onychinalis Guenée, 1854. The species has been recorded from SE-Saudi-Arabia, Yemen and Dhofar [23-25]. Further two specimens similar to G. onychinalis in wing pattern and genital-morphological characters were collected by the author in 2019 near the Yemen border. There are significant external and genital-morphological differences between the specimens of the sample, G. onychinalis and six further species similar in wing pattern, which result in the description of the new species Glyphodes leucomesalis Seizmair, sp.nov.

\section{Material and Methods}

\subsection{Sampling}

The material presented in this paper was sampled by the author in two research expeditions to Dhofar, the south-western province of Oman in November 2018 and in February 2019. The collecting sites are situated on the southern slopes of the western parts of Jabal Al Qamar, a coastal mountain system ranging from the western surroundings of the province capital Salalah to the Yemen border (Figure 1). The specimens were captured at night by means of a light-trap equipped with a $20 \mathrm{~W}$ tube of infra-blue light.

\subsection{Macro-Preparation and Dissection}

The adults were photographed with a SONY HX400V camera after relaxation and subsequent preparation.

For examining the genitalia, dissection, preparation and slide-mounting techniques were applied on the specimens on the basis of the protocol described in Robinson [26]. The slides were photographed with a SONY DSC100V camera under a 40x zoom.

The images were optimized by means of the software Ps Adobe Photoshop, Version 21.0.2.

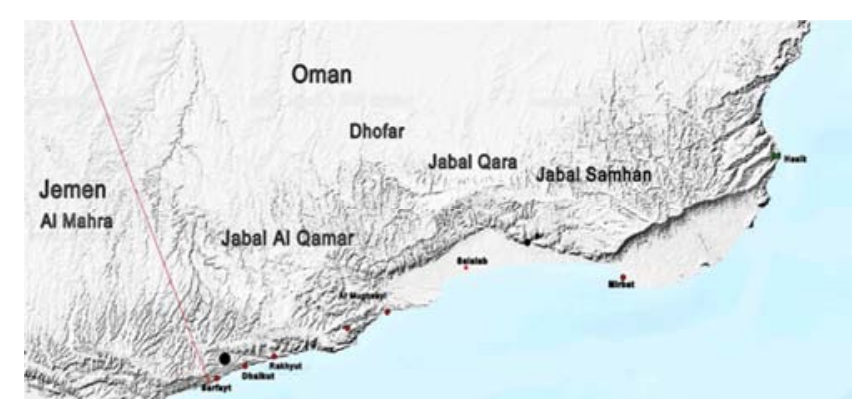

Figure 1. Collection site in Oman, Dhofar, Jabal Al Qamar, near the Yemen border (black point).

\subsection{Morphological Analyses}

Morphometric analyses of wing patterns and genital-morphological structures were done on the images. Structural ratios were measured and calculated by means of the imaging software ZEISS AxioVision, Version 4.8.

\subsection{Terminology and Abbreviations}

The descriptions of the genitalia and of wing pattern elements are based on the terminology in Maes [27]. The nomenclature of the venation follows Shaffer \& Munroe [11]. The feature states referred to in the descriptions and diagnoses 
are based on the feature space given in Mally et al. [1]. Abbreviations:

ZSM Zoological State Collection Munich, Germany

\section{Results}

Herpetogramma debilis Seizmair, sp.nov. (Figures 2-3)

Material: Holotype: $\widehat{\partial}$, Oman, Dhofar, $20 \mathrm{~km}$ E Sarfait, Road 47, Jebel Al Qamar, 960 m, 07-XI-2018, leg. M. Seizmair, coll. ZSM, slide no. GPPYR1519.

Paratype: same collection data as holotype, leg. et coll. M. Seizmair, 1 ô, slide no. GPPYR1619.

External features (Figure 2): Wing span of the holotype $18,5 \mathrm{~mm}$, wing span of the paratype $22,6 \mathrm{~mm}$.

Head: Frons and vertex whitish-grey. Labial palpus greyish, dorsally interspersed with darkish-brown to blackish scales, rounded distally, porrect, 2,4 times as long as the diameter of the eye, 2,3 times as long as wide. Maxillary palpus with darkish-grey sales in the segment 1 , scaling in all the other segments constantly black, half as long as the labial palpus, distally rounded. Antennae filiform ciliate, flagellum hyaline, ciliae whitish-grey.

Thorax: Scaling of the prothorax whitish-grey, meso- and metathorax with whitish-grey scales laterally and with ochre scales dorsally and ventrally. Scaling of the legs whitish-grey, interspersed with ochre scales at the segments. Forelegs with two tibial spurs of different lengths, the longer one being 1,8 times as long as the shorter one. Tegula scaled black.

Forewing upper side: Ground greyish-brown. Costal border, apical area and external area interspersed with yellowish-brown scales. Basal area interspersed with darkish-brown to blackish scales immediately below the costal border, with two orbiform stigmata, strongly differing in size, located on the sub-costa $(\mathrm{Sc})$ and on the anal border respectively. Antemedial, postmedial and anteterminal lines present, yet strongly interrupted, black. Antemedial line developing from the discoidal cell and terminating at the anal border. Postmedial line developing from the sub-costa $(\mathrm{Sc})$, with two $90^{\circ}$ curvatures at $\mathrm{M} 1$ and $\mathrm{CuA} 2$, running straight from the Sc up to the first curvature, slanted between the two curvatures, with another slight angle between the second $90^{\circ}$ curvature at $\mathrm{CuA} 2$ and the anal border. Anteterminal line strongly interrupted, consisting of a row of fuscous points. Discocellular spot black, reniform. Forewing underside like forewing upper side.

Hindwing upper side: Ground like forewing. Medial and external areas sporadically interspersed with yellowish scales. Antemedial line black, strongly interrupted, running between $\mathrm{CuA} 2$ and $\mathrm{A} 1+2$, paired with a small black stigma between M1 and M2. Postmedial line black, developing immediately below M1, terminating at A3, strongly tapering from M2 onwards. Anteterminal line black and strongly interrupted. Terminal line yellowish-fuscous and strongly interrupted.

Male genitalia (Figure 2): Uncus with a deep lateral concave curvature and a strong dorsal convexity at its base, transition between the basal uncus and the tegumen with a lateral triangular-shaped offset, ratio width of the base / total length of the uncus $1 / 1,65=0,6$. Apical uncus acute, with lateral fields of elongate chaetae forming a triangular shape and ranging over $44 \%$ of the length of the uncus proximad, ratio maximum length of the chaetae / total length of the uncus $1 / 3$. Ratio length of the uncus / length of the tuba analis $1 / 1,3$. Tuba analis with a fine, stroke-like sclerite ranging over half of its total length.

Valva elongate, apex evenly rounded, basal costa inflated and convex with pencil-shaped projections directed anteriad, post-basal and distal costa straight. Sacculus triangular-shaped basally, strongly tapering dorso-distally. Coremata pencil-shaped, rounded proximally.

Saccus v-shaped with a protruding keel at its ventral tip. Phallus apodeme of the aedeagus with a longitudinal sclerotized strip, which is acute proximally. Posterior phallus apodeme with additional stroke-shaped sclerotizations on the lateral borders, bare from any sclerotizations in the interior. Cornuti absent.

Table 1. Differential diagnosis of Herpetogramma debilis Seizmair, sp.nov. based on the male genitalia.

\begin{tabular}{|c|c|c|c|c|c|}
\hline Characters and character states & $\begin{array}{l}\text { H. debilis } \\
\text { Seizmair sp.nov }\end{array}$ & $\begin{array}{l}H . \\
\text { juba }\end{array}$ & $\begin{array}{l}\text { H. } \\
\text { continualis }\end{array}$ & $\begin{array}{l}\text { H. } \\
\text { mutualis }\end{array}$ & $\begin{array}{l}\text { H. } \\
\text { admensalis }\end{array}$ \\
\hline $\begin{array}{l}\text { Basal uncus: presence of a significant convex curvatures on the lateral border: } \\
\text { (0) absent; (1) present }\end{array}$ & 1 & 0 & 0 & 0 & 0 \\
\hline $\begin{array}{l}\text { Basal uncus: shape of the dorsal border: } \\
\text { (0): straight; (1) convex; (2) concave }\end{array}$ & 1 & 1 & 0 & 0 & 2 \\
\hline $\begin{array}{l}\text { Transition basal uncus - tegumen: (0): smooth; (1) with a strong lateral } \\
\text { triangular-shaped offset, (2) with slight convex angles laterally }\end{array}$ & 1 & 2 & 0 & 2 & 0 \\
\hline $\begin{array}{l}\text { Ratio maximum width of the basal uncus/total length of the uncus: } \\
(0): \leq 0,5 ;(1)>0,5\end{array}$ & 1 & 0 & 0 & 0 & 0 \\
\hline $\begin{array}{l}\text { Sacculus: presence of a stroke-like projection in the dorso-distal area directed } \\
\text { costad: (0) absent; (1) present }\end{array}$ & 0 & 1 & 0 & 1 & 0 \\
\hline $\begin{array}{l}\text { Sacculus: shape of the basal area: } \\
\text { (0) rounded; (1) triangular-shaped }\end{array}$ & 1 & 0 & 0 & 0 & 0 \\
\hline Shape of the saccus: (0) U-shaped; (1) V-shaped & 1 & 1 & 0 & 1 & 1 \\
\hline $\begin{array}{l}\text { Saccus: Presence of a protruding keel at the anterior end: (0) absent; (1) present } \\
\text { Aedeagus: Sclerotizations in the posterior portion of the phallus: (0): absent, (1) }\end{array}$ & 1 & 1 & 0 & 1 & 1 \\
\hline $\begin{array}{l}\text { lateral borders sclerotized, no sclerites in the interior (1) several small, orbicular } \\
\text { sclerites in the interior; ( } 2 \text { ) one rectangular-shaped sclerite extending over }> \\
80 \% \text { of the posterior portion of the phallus }\end{array}$ & 0 & 1 & 2 & 2 & 0 \\
\hline
\end{tabular}


Female genitalia: The female genitalia are unknown.

Differential diagnosis: The closest species are Herpetogramma juba Shaffer \& Munroe, 2007, Herpetogramma continualis Shaffer \& Munroe, 2007, Herpetogramma mutualis Zeller, 1852, Herpetogramma admensalis Walker, 1859. The new species is externally distinguished from these species in the strongly interrupted antemedial and postmedial lines in the fore- and hindwings. The key differences are in the male genitalia (Table 1). The male genitalia of the comparative species are described and figured in [7, 11, 28]. Bionomics: The type material was collected in an escarpment in the montane zone of the Jabal Al Qamar. The life cycle is unknown.

Distribution: Known only from the type locality.

Etymology: The epitheton refers to one of the characteristic external features, the strongly interrupted lines in the fore- and hindwings (lat. debilis=broken, weak).

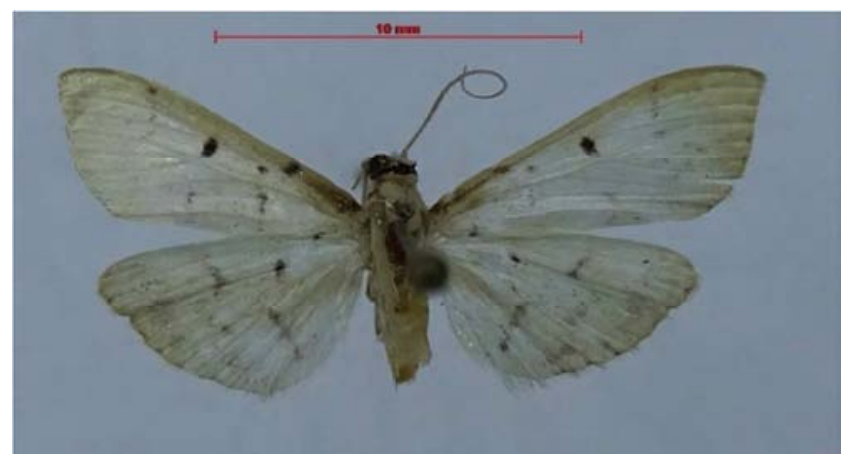

Figure 2. Herpetogramma debilis Seizmair, sp.nov, holotype, adult, ठิ, Oman, Dhofar, $20 \mathrm{~km}$ E Sarfait, Road 47, Jebel Al Qamar, $960 \mathrm{~m}$.

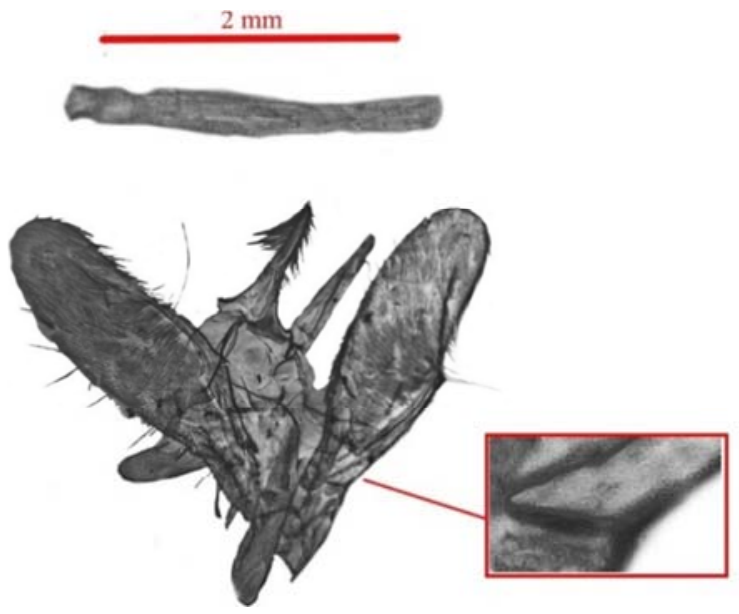

Figure 3. Herpetogramma debilis Seizmair, sp.nov. holotype, male genitalia, slide no. GPPYR1519, sacculus of the right valva zoomed (red box).

Notarcha viridalis Seizmair, sp.nov. (Figures 4-5)

Material: Holotype: ð̄, Oman, Dhofar, 20 km E Sarfait, Jebel Al Qamar, 960 m, 07-XI-2018, leg. M. Seizmair, coll. ZSM, slide no. GPPYR2319. Paratype: same collection data as holotype, leg. et coll. M. Seizmair, $1 \hat{\jmath}$, slide no. GPPYR2219.

External features (Figure 4): Wingspan of the holotype: 21,3 $\mathrm{mm}$, wingspan of the paratype: $23,5 \mathrm{~mm}$. Head: Frons and vertex whitish-grey. Labial palpus porrect, distal end acute, segment 1 proximally tapered, with darkish-brown scales, segment 2 broadened, scaling from the segment 2 onwards light-brown, sporadically interspersed with black scales, with whitish-grey chaetae supero-laterally, ratio length/diameter of the eye $1 / 2,5$. Maxillary palpus broad, rounded distally, scaling constantly darkish-brown, ratio width/length $1 / 2$, ratio length of the maxillary palpus/length of the labial palpus $1 / 2$. Antennae filiform ciliate, flagellum darkish-brown, ciliae whitish-grey. Thorax: scaling whitish-grey, interspersed with darkish-brown to black scales dorsally. Fore-and hindlegs with whitish-grey ground scaling, tibia interspersed with darkish-brown scales, tibial spurs equal in length. Abdomen: Ventral and lateral scaling whitish-grey, dorsal scaling inter-segmentally greenish-yellow, on the segments whitish-grey.

Forewing upper side: ground whitish-grey. Basal area with two black stigmata of irregular shape on the anal and costal border. Costal border with two further black stigmata ante-medially and postmedially. Discal spot well developed, claviform, black with a white kernel. Costal border with greenish-yellowish scales. Antemedial, postmedial and ante-terminal lines greenish-yellow, developing from the costal border. Antemedial line straight, strongly interrupted. Medial line at M1 with a convex curvature, interrupted at $\mathrm{CuA} 1$, then running straight to the anal border. Postmedial line developing from the postmedial subcostal spot, with angles at M1 and M3, connected with the medial line at $\mathrm{CuA} 1$. The postmedial and medial lines thus form a structure of ellipsoid shape. Ante-terminal line strongly tapering from M1 onwards, terminating at the anal border, with a strong $90^{\circ}$ angle at $\mathrm{CuA} 2$ opened proximad. Terminal line black, straight. Fringe greenish-yellow. Forewing underside like forewing upper side.

Hindwing upper side: ground like forewing. Basal, medial, postmedial and anteterminal lines greenish-yellow. Basal line ranging from Rs to $\mathrm{A} 1+2$. Medial line angled at $\mathrm{M} 2$, ending at $\mathrm{A} 1+2$. Postmedial line sinusoid with angles at $\mathrm{M} 2$ and $\mathrm{CuP}$ and ending at the anal border. Anteterminal line developing from $\mathrm{Sc}+\mathrm{R} 1$, running parallel to the termen and ending at the anal border. Hindwing underside like hindwing upper side.

Male genitalia (Figure 5): Uncus elongate, basis trapezoid, distal fourth with an enlarged offset of slightly bulbous shape with several fine stroke-like sclerites in the interior and several short chaetae supero-laterally.

Valva 2,2 times as long as wide, costa and ventral border running straight in the basal and post-basal areas, distally with rounded convexities at the transitions to the apex. Apex medially rounded. Rounding of the costal border strongly sclerotized and covered with a tuft of long chaetae. Basal costa inflated and with broad triangular- shaped projections directed towards the tegumen. Fibula developing in the proximal third of the valva, with a convex curvature anterio-laterally, directed ventrad, not exceeding the ventral border of the valva. Basal sacculus rounded.

Tegumen rectangular-shaped with a pair of elongate rod-shaped sclerites running slant and forming a trapezoid structure. Saccus v-shaped. Coremata pads present, rounded proximally, elongate, ratio width/length $1 / 2,5$. 
Phallus apodeme of the aedeagus with three cornuti developing from the distal portion to the middle of the phallus, two of them of equal strength, the third one more slender and partially occluded by the two stronger developed cornuti.

Differential diagnosis: The new species is attributed to the Notarcha quaternalis Zeller, 1832 species complex sensu Shaffer and Munroe [11, 29]. In this species group, the species closest to the new species are Notarcha quaternalis Zeller, 1832 and Notarcha digitalis Shaffer \& Munroe, 2007. The three species are externally distinguished from the other species of this complex - Notarcha cassualis Walker, 1859, Notarcha temeratalis Zeller, 1852 and Notarcha muscerdalis Zeller, 1852
- by the three black stigmata on the forewing costa, the connectedness of the medial and postmedial lines forming an ellipsoid shape and the dark scaling of the labial palpus.

The new species is externally distinguished from $N$. quaternalis and $N$. digitalis by the greenish-yellow scaling of the longitudinal lines of the fore- and hindwings. In each of the comparative species the longitudinal lines are scaled darkish-yellow. The whitish-grey setae on the labial palpus in the new species are absent in each of the comparative species.

The main key differences are in the male genitalia (Table 2). The male genitalia of $N$. quaternalis and $N$. digitalis are figured in Guillermet and in Shaffer and Munroe [7, 11].

Table 2. Differential diagnosis of Notarcha viridalis Seizmair sp. nov. based on the male genitalia.

\begin{tabular}{|c|c|c|c|}
\hline Characters and character states & $\begin{array}{l}\text { N. viridalis } \\
\text { Seizmair } \\
\text { sp.nov }\end{array}$ & $\begin{array}{l}\text { N. } \\
\text { quaternalis }\end{array}$ & $\begin{array}{l}\text { N. } \\
\text { digitalis }\end{array}$ \\
\hline $\begin{array}{l}\text { Length of the uncus: (0) shortened with the distal end not exceeding sub-apical area of the valva; (1) } \\
\text { elongate, exceeding the apex of the valva }\end{array}$ & 1 & 0 & 1 \\
\hline Shape of distal uncus: (0) finger-shaped, rounded; (1) with a slightly bulbous-shaped distal offset & 1 & 0 & 0 \\
\hline $\begin{array}{l}\text { Presence of a pair of elongate sclerites in the tegumen: (0) absent; (1) running slant forming a quasi } \\
\text { triangular-sahped structure; (2) with convex curvatures medially and concave angles proximally, forming an } \\
\text { omega-shaped structure }\end{array}$ & 1 & 0 & 2 \\
\hline $\begin{array}{l}\text { Presence of projections at the basal costa of the valva directed towards/into the tegumen: }(0) \text { absent; (1) } \\
\text { distally stout, of trapezoid shape; (2) rectangular-shaped }\end{array}$ & 2 & 0 & 1 \\
\hline Shape of the post-basal costa: (0) straight, (1) convex & 0 & 0 & 1 \\
\hline Shape of the distal costa: (0) straight, (1) convex & 1 & 0 & 0 \\
\hline Presence of a chaetose sclerotization on the distal costa: (0) absent; (1) present & 1 & 0 & 1 \\
\hline Length of the fibula: $(0)$ not exceeding the ventral border; (1) exceeding the ventral border & 0 & 1 & 0 \\
\hline $\begin{array}{l}\text { Shape of the fibula: (0) with a convex curvature anterio-laterally, forming a } 45^{\circ} \text { angle with the ventral } \\
\text { border; (1) straight, bared from any curvatures, running quasi parallel to the ventral border }\end{array}$ & 0 & 0 & 1 \\
\hline Presence of a diverticulum on the posterior border of the fibula: (0) absent; (1) present & 0 & 0 & 1 \\
\hline Shape of the sacccus: (0) U-shaped; (1) V-shaped & 1 & 0 & 0 \\
\hline Presence of a protruding keel at the anterior end of the saccus: (0) absent; (1) present & 0 & 1 & 1 \\
\hline Presence of coremata pads: (0) absent; (1) proximally rounded (2) quasi triangular-shaped, acute proximally & 1 & 0 & 2 \\
\hline Aedeagus: number of cornuto in the phallus apodeme: $(0)$ one; $(1)$ two; (2) three & 2 & 0 & 1 \\
\hline
\end{tabular}

Bionomics: The type material was collected in an escarpment in the montane zone of the Jabal Al Qamar. The life cycle is unknown.

Distribution: Known only from the type locality.

Etymology: The epitheton refers to one of the characteristic external features, the greenish-yellow line pattern (lat. viridus $=$ green).

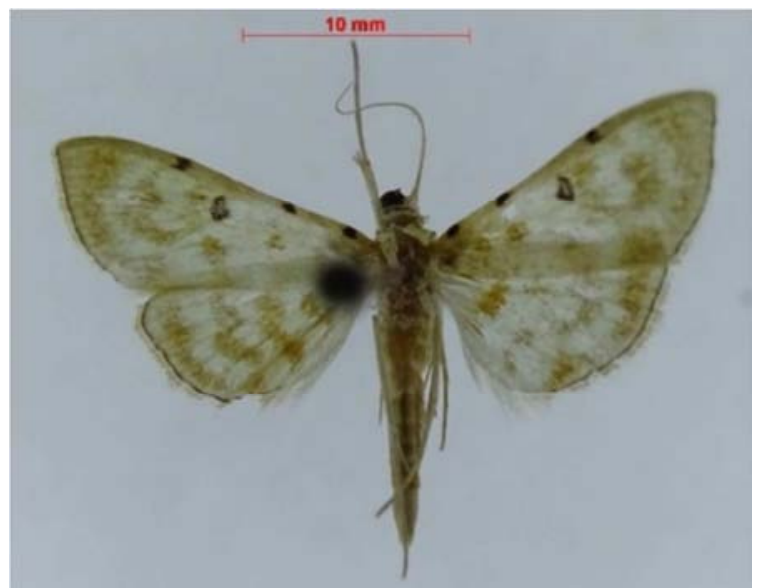

Figure 4. Notarcha viridalis Seizmair, sp.nov., holotype, adult, $\hat{\sigma}$, Oman, Dhofar, $20 \mathrm{~km}$ E Sarfait, Road 47, Jebel Al Qamar, $960 \mathrm{~m}$.

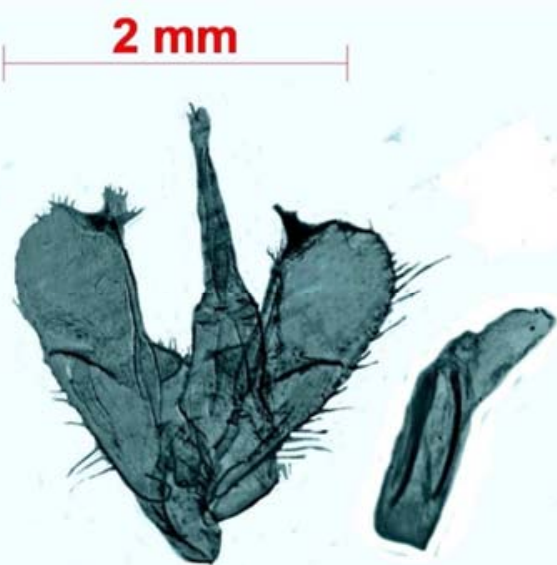

Figure 5. Notarcha viridalis Seizmair, sp.nov, holotype, male genitalia, slide no. GPPYR2319.

Glyphodes leucomesalis Seizmair, sp.nov. (Figures 6 - 8)

Material: Holotype: $\widehat{\jmath}$, Oman, Dhofar, $20 \mathrm{~km}$ E Sarfait, Jebel Al Qamar, 960 m, 03-II-2019, leg. M. Seizmair, coll. ZSM, slide no. GPPYR2819. Paratype: Oman, Dhofar, 4km W Dalkuth, 04. II. 2019, leg. et coll. M. Seizmair, 1 q, slide no. GPPYR2519.

External features (Figure 6): Wingspan of the holotype 21,5 
$\mathrm{mm}$, wingspan of the paratype $17,7 \mathrm{~mm}$.

Head: Frons, vertex and maxillary palpus scaled whitish-grey. Labial palpus with a whitish grey ground scaling interspersed with darkish-brown scales in the segments 2 and 3, equal in length with the diameter of the eye. Antennae filiform ciliate in both sexes, flagellum yellowish-brown up to the distal fifth, distal fifth darkish-brown to black, ciliae whitish-grey.

Thorax: Ventral and lateral scaling constantly whitish-grey, dorsal scaling of the prothorax ochre, of the mesothorax darkish-brown to black, of the metathorax darkish-grey interspersed with yellowish scales. Hindlegs and femur of forelegs constantly whitish-grey, transition from the femur to the tibia of the foreleg with darkish-brown scales, tibia of the foreleg darkish-grey interspersed with yellowish scales. Abdomen: ventral and lateral scaling whitish-grey, dorsal scaling whitish-grey between the segments, yellowish-brown on the segments.

Forewing upper side: Ground whitish-grey. Medial and post-medial areas between the costa and R1 interspersed with yellowish scales. Discal spot split up into a pair of small black stroke-like stigmata. Antemedial and postmedial bands broken into a paired structure of adjacent greenish-fuscous lines, with the band in between concolorous with the ground. Medial band broad, yellowish-fuscous, bifurcating at M3 into two complex lines, which are of the same paired structure as the antemedial and postmedial lines respectively and form together an eye-shaped structure. Postmedial band terminating at $\mathrm{CuA1}$, strongly angled at $\mathrm{M} 2$, with the angle opened proximad. Anteterminal line simple, yellowish-fuscous, terminating at M3. Terminal line darkish-fuscous, straight. Fringe yellowish-grey. Forewing underside like forewing upper side with an additional yellowish scaling in the postmedial and anteterminal areas.

Hindwing upper side: Medial, postmedial and anteterminal lines of the same scaling as the lines of the forewing. Medial line of a paired structure like the antemedial and postmedial lines of the forewing. Postmedial and anteterminal lines simple, connected at $\mathrm{CuA} 2$. Terminal line and fringe like in the forewing. Hindwing underside like hindwing upper side.

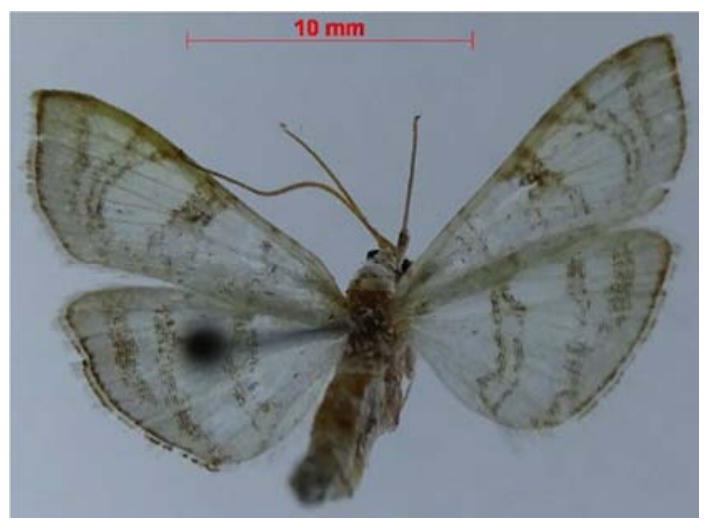

Figure 6. Glyphodes leucomesalis Seizmair, sp.nov., holotype, adult, §ิ, Oman, Dhofar, $20 \mathrm{~km}$ E Sarfait, Road 47, Jebel Al Qamar, 960m.

Male genitalia (Figure 7): Uncus: composed of a neck and a beak forming a $90^{\circ}$ - angle, with the neck membranous and the beak with a triangular-shaped sclerite ranging over its entire length, several short chaetae on the ventral border and a knob-like sclerotization on the apex. Tegumen of sub-triangular shape with several stroke-like sclerites, ratio maximum width/height 1/1,2. Tuba analis present, articulating with the ventro-lateral border of the tegumen, equal in length with the height of the tegumen and with a rod-shaped sclerite in its interior.

Valva: ratio maximum width/maximum length $1 / 1,4$. Costal border straight, post-basal and dorso-distal areas interspersed with short chaetae. Basal ventral border convex, the post-basal and distal area quasi perpendicular with the basal portion with a strong concavity ranging up to the apex. Apex obliquely rounded towards the costa with a tuft of long chaetae on the transition to the costa. Basal ventral border with a process, which is pointed anteriad, strongly broadened and quasi triangular-shaped in the posterior third, then strongly tapering anteriad forming a pencil-shaped structure. The interior of the valva is characterized by the presence of an editum sensu Maes and a fibula [27]. The fibula is equal in length with $35 \%$ of the maximum width of the valva, running straight and directed costad. Its basis is interspersed with several chaetae dorso-laterally. Sacculus strongly tapered and acute in its distal portion, inflated and broadened medially, its distal end with an elongate rod-shaped projection running to the post-basal ventral border.

Saccus: strongly broadened, stout, of trapezoid shape, ratio maximum width/height $1 / 1$, anterior border with a small diverticulum medially and with a strongly broadened falciform projection pointing anteriad, posterior border with a pencil-shape projection developing into the basal area of the valva, with the anterior half of asymmetrical, semi-ovoid shape.

Aedeagus: Phallus apodeme with an elongate pencil-shaped cornutus extending from the posterior portion to the apex. Posterior portion with several plate-shaped and rod-shaped sclerites.

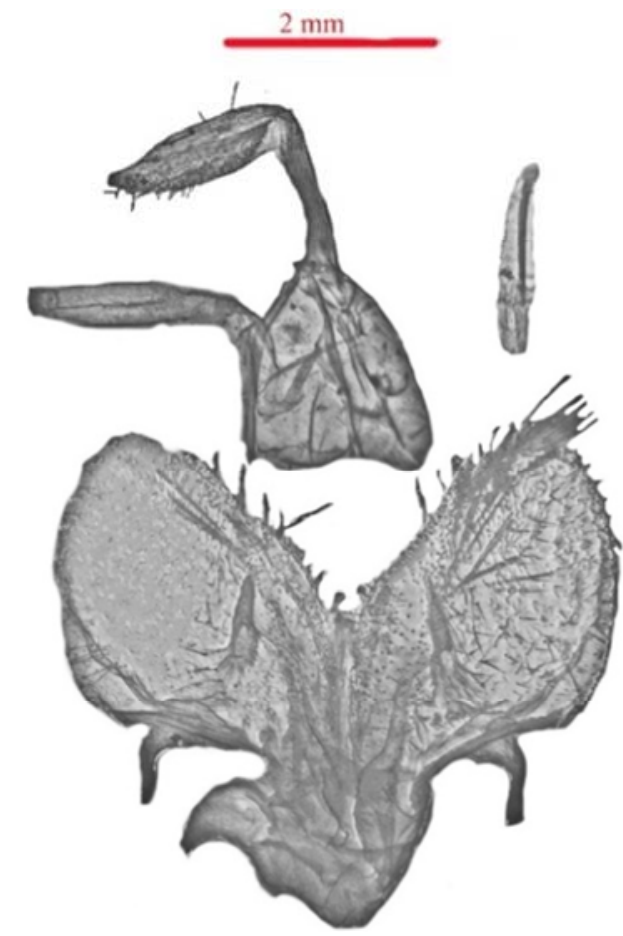

Figure 7. Glyphodes leucomesalis Seizmair, sp.nov., holotype, male genitalia, slide no. GPPYR2819. 


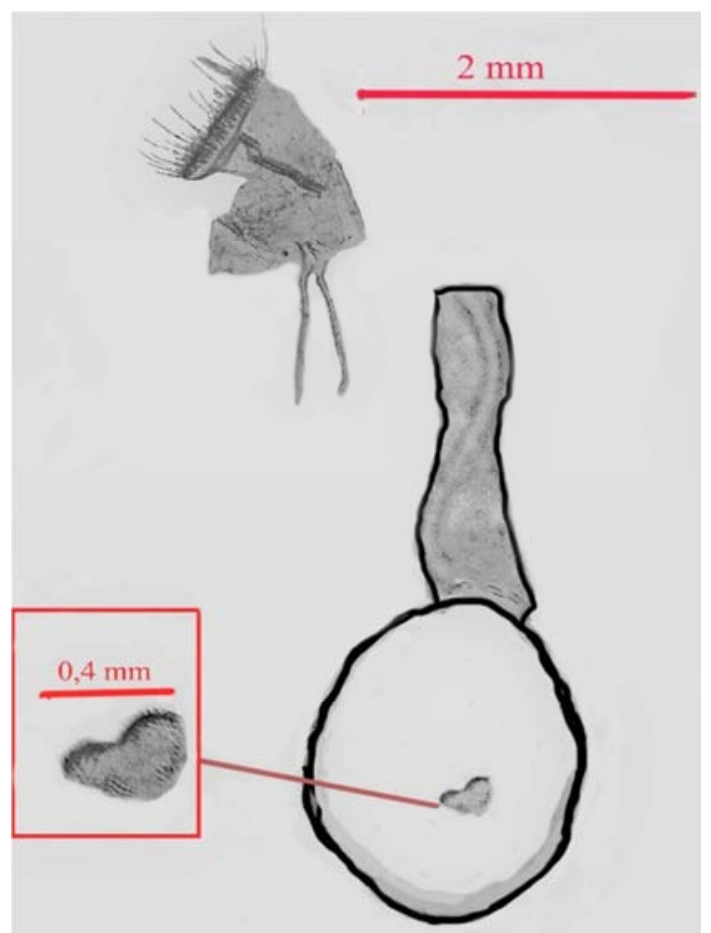

Figure 8. Glyphodes leucomesalis Seizmair, sp.nov., paratype, female genitalia, slide no. GPPYR2519, Oman, Dhofar, $4 \mathrm{~km} W$ Dalkuth, signum zoomed (red box).

Female genitalia (Figure 8): Corpus bursae with a heart-shaped signum. Ductus bursae membranous, of constant width, equal in length with the corpus bursae. Ostium of trapezoid shape. Papillae anales orbiform, chaetose. Ratio of the lengths of the apophyses posteriores/apophyses anteriores $1 / 1,8$.

Differential diagnosis: The new species shares the basic forewing pattern consisting of narrowed longitudinal lines in the basal, antemedial and anteterminal areas and a broadened medial band bifurcating at M3 with G. onychinalis, Glyphodes caesalis Walker, 1859, Glyphodes flavizonalis Hamppson 1898. From all these species the new species differs in the interconnectedness of the forewing longitudinal lines: In each of the latter species, the longitudinal lines are interconnected the medial line with the postmedial line, the antemedial line with the medial line thus forming ellipsoid, eye-shaped structures, in the new species the forewing longitudinal lines all run separately from each other.

The species differ furthermore in the number of longitudinal lines in the basal-antemedial-postmedial-anteterminal areas: $0-1-1-1$ in the new species, 2-1-1-2 in G. onychinalis, 1-1-1-0 in G. caesalis, 1-2-1-1 in G. flavizonalis.

The forewing patterns of longitudinal lines shared by the four species encompass lines split up into a pair of darkish-brown outer lines and a band in between and simple lines. The portions of simple lines and lines split up differ inter-specifically:

The number of lines split up in the basal-antemedial-postmedial-anteterminal areas is 0-1-1-0 in the new species, 2-1-1-0 in G. onychinalis, 1-1-1-0 in G. caesalis, 0-1-0-0 in G. flavizonalis.
In the case of lines split up, the scaling of the band between the bordering lines differs interspecifically: concolorous with the greyish-white ground in the new species, contrasting with the ground and fulvous in each of the other comparative species.

Further species with similar forewing longitudinal line patterns are Glyphodes xanthostola Hampson, 1910, Gyphodes parallelalis Gaede, 1917, Glyphodes ochripictalis Strand, 1912. Each of them differs from the species sample discussed above in the absence of a bifurcation in the medial band. Furthermore, in each of the three species, all the longitudinal lines are split up, with the scaling of the middle band ochreous to darkish-orange.

The new species is very close to $G$. onychinalis in genital-morphological characters. In the male genitalia the two species share the beak-shaped uncus and the triangular-shape of the tegumen. In the female genitalia, the two species share the heart-shaped signum in the corpus bursae. The two species are distinguished in the male and female genitalia as follows. The genitalia of $G$. onychinalis are described in figured in Rathikannu and Chitra [20].

Male genitalia (Figure 7): Valva: Projections on the border: located on the basal ventral border in the new species, on the costa in $G$. onychinalis. Fibula: directed costad, running parallel to the base in the new species, directed dorsad, running orthogonal to the base in $G$. onychinalis. Base of the fibula connected with the distal sacculus in $G$. onychinalis, separated from the sacculus in the new species. Shape of the cucullus: obliquely rounded towards the costal border and narrowed in the new species, strongly broadened and flattened in G. onychinalis. Editum: present in the new species, absent in $G$. onychinalis. Sacculus: basal and medial portions strongly broadened and of constant width, distal portion tapered in G. onychinalis, medial portion strongly broadened, distal and basal portions strongly tapered in the new species. Furthermore, in the new species an elongate, stroke-shape process develops from the distal portion of the sacculus to the post-basal ventral border, which is absent in G. onychinalis.

Saccus: asymmetrical with a projection and a diverticulum dorso-laterally in the new species, symmetrical and bare of any projections in G. onychinalis.

Tegumen: Ratio maximum width/length $1 / 2$ in $G$. onychinalis, 1/1,2 in the new species. Tuba analis articulating with the ventro-lateral border of the tegumen present in the new species, absent in $G$. onychinalis.

Uncus: Ratio length neck/maximum length beak $<1$ in the new species, $>1$ in $G$. onychinalis.

Aedeagus: In $G$. onychinalis there is a stroke-shaped sclerite near the apex, which is absent in the new species. In the new species, there is a plate-shaped sclerite in the posterior portion, which is absent in G. onychinalis.

Female genitalia: Ductus bursae tapering in its posterior half in G. onychinalis, of constant width in the new species, sclerotized at the transition to the ostium in G. onychinalis, bare of sclerotizations in the new species.

Remarks: It should be noted that there is no constant correlation between the forewing longitudinal line pattern 
shared by the new species, G. onychinalis and 6 further species of the genus and the shape of the uncus as shared by the new species and $G$. onychinalis. In $G$. caesalis the beak-shape in the uncus is absent [19]. The new species and $G$. onychinalis share the beak-shape in the uncus with Glyphodes actorionalis Walker, 1859 and Glyphodes vertuminalis Guenée, 1854 [19, 22]. Yet, a longitudinal line pattern is absent in the forewings of each of these two species. $G$. vertuminalis shows a unicolorous green wing-pattern. $G$. actorionalis is similar in wing pattern to Glyphodes bivitreealis Guenée, 1854.

Bionomics: Life-cycle and premature stages unknown. The type habitat is situated in an escarpment.

Distribution: Known only from the type locality.

Etymology: The epitheton refers to one of the differential features in the forewing pattern - the greyish-white scaling in the space between the bordering lines of the composite longitudinal lines (Greek: leucos $=$ white, $\operatorname{mesos}=$ middle).

\section{Discussion}

\subsection{Phylogenetic Placement}

The new species Herpetogramma debilis Seizmair, sp.nov. and Notarcha viridalis Seizmair, sp.nov belong to sibling species complexes the members of which are primarily distinguished by genital-morphological characters. The identification of each of these species groups - group A of the genus Herpetogramma Lederer, 1883 and the $N$. quaternalis complex are based on external similarities in wing-pattern exclusively. The correlation of external characters, morphological and DNA- based markers in these species groups need further investigation.

Glyphodes leucomesalis Seizmair, sp. nov. is closely related to $G$. onychinalis externally in the forewing pattern of narrowed longitudinal lines and morphologically. Yet, the two species significantly differ externally in the interconnectedness of the longitudinal lines and in the male genitalia.

The new species is attributed to the preliminary species group 2 of the genus Glyphodes Meyrick, 1884 set up in Sutrisno [15-18]. This species cluster encompasses $G$. onychinalis and 6 further species. The new species shares with the species of this clade the triangular-shaped tegumen and sclerotized structures in the tegumen. These characters are identified as apomorphies of this clade in Sutrismo [17].

The phylogenetic placement of the new species in the genus

Glyphodes Meyrick, 1884 and the phylogenetic structure of the genus as a whole are still in need of further investigation. The species sample, on which the studies of Sutrisno are based cover less than $10 \%$ of the total species of the genus.

\subsection{Distribution}

The distribution of the three species is still unexplored. For Herpetogramma debilis Seizmair, sp.nov. and Notarcha viridalis Seizmair, sp.nov both allopatric and parapatric distribution patterns with respect to known species on the African Continent are thinkable. Glyphodes leucomesalis
Seizmair, sp.nov. shows parapatric distribution with regard to $G$, onychinalis, yet the potential presence of the new species on the African Mainland is in need of further investigation.

\section{Conclusion}

In this paper three new species belonging to three different genera - Herpetogramma Lederer, 1883, Notarcha, Meyrick, 1884 and Glyphodes Meyrick, 1884 were described on the basis of samples collected in south-western Oman.

Preliminary phylogenetic placements of the new taxa in sibling species complexes in the genera Herpetogramma Lederer, 1883 and Notarcha, Meyrick, 1884 and in a monophyletic sub-clade of the genus Glyphodes Meyrick, 1884 identified in molocular-genetic studies by Sutrisno were discussed [15-18]. The need of revisions of the genera covered by this study by means of integrative approaches, which incorporate external characters, morphological and molecular genetic markers for further corroboration of the species complexes and a thoroughgoing understanding of their phylogenetic and taxonomic status was discussed.

Further distributional data on the new species described in this study as well as further new species in the respective genera are expected from further field research in the coastal mountain system in Dhofar and in Yemen and in the Asir Mountain system in SE- Yemen and SE- Saudi Arabia.

\section{Acknowledgements}

This paper is registered in the ZooBank under the LSID zoobank.org:pub:B2764E6F-0212-4C0F-AAF7-852E50E2C C3F.

The author thanks Eva Karl (SNSB/ZSM, Munich, Germany), Andreas Segerer (SNSB/ZSM, Munich, Germany) and Gerhard Haszprunar (SNSB/ZSM, Munich, Germany) for technical support in his field research and in the compilation of the manuscript. Furthermore, the author thanks Rudi Verovnik (Biotechnical Faculty, University of Ljubljana, Slovenia) and Werner Back (Freising, Germany) for discussion. The author devotes this paper to his father Werner Seizmair $(\dagger)$, a grand collector and lepidopterologist in deep gratitude for constant support, discussion, advice and encouragement. He died unexpectedly during the research phase for this paper.

\section{References}

[1] R. Mally, J. Hayden, C. Neinhuis, B. H. Jordal, and M. Nuss, "The phylogenetic systematics of Spilomelinae and Pyraustina (Lepidoptera: Pyraloidea: Crambidae) inferred from DNA and morphology," Arthropod Systematics and Phylogeny, vol. 77 (1), pp. 141-204, 2019.

[2] M. Nuss, B. Landry, R. Mally, F. Vegliante, A. Tränkner, F. Bauer, J. Hayden, A. Segerer, R. Schouten, H. Li, T. Trofimova, M. A. Solis, J. De Prins and W. Speidel, "Global Information System on Pyraloidea," World Wide Web electronic publication (http://www.pyraloidea.org) [30.09.2020]. 
[3] J. S. Irungbam, M. S. Chib, and K. Wangdi, "Taxonomic review of the superfamily Pyraloidea in Bhutan," Journal of Asia-Pacific Biodiversity, vol. 9, pp. 355-382, 2016.

[4] J. Ko, U. Bayarsaikhani, B. Park, T. Lee, Y. Cha, C. Jang, J. K. Lee, and Y. Baee, "Exoasota pursatensis Ko \& Bae, new genus and species of the Spilomelinae (Lepidoptera: Pyraloidea: Crambidae) from Indochina," Zootaxa, vol. 4838 (1), pp. 119-127, 2020.

[5] B. Landry, "Taxonomic Revision of the Spilomelinae (Lepidoptera, Pyralidae s. 1.) of the Galapgos Islands, Ecuador," Revue Suisse de Zoologie, vol. 123 (2), pp. 315-399, 2016.

[6] M. Bippus, "Pyraloidea of Mauritius and neighbouring islands (Lepidoptera)," Phelsuma, vol. 27, pp. 36-57, 2019.

[7] C. Guillermet, The Heterocera of La Réunion, Volume 3 Pyralidae and Crambidae. Saint-Paul: Nature Discovery, 2009.

[8] C. Guillermet, "Contribution to the study of the Heterocera of La Réunion: revision of the genera Herpetogramma Lederer, 1863 and Syllepte Hübner, 1823 and description of six new species (Lepidoptera Crambidae Spilomelinae)," The Entomologist, vol. 64 (3), pp. 201-210, 2008.

[9] K. V. N. Maes, "Crambidae: Noordinae, Odontiinae, Pyraustinae, Spilomelinae (Lepidoptera: Pyraloidea)," Esperiana Mémoir, vol. 1, pp. 221-234, 2004.

[10] F. Slamka, Pyraloidea of Europe, Volume 3: Pyraustinae \& Spilomelinae. Bratislava: Frantisek Slamka, 2013.

[11] J. C. Shaffer and E. G. Munroe, "Crambidae of Aldabra Atoll (Lepidoptera: Pyraloidea)," Tropical Lepidoptera, vol. 14, pp. 1-110, 2007.

[12] J. E. F. Asselbergs, "Order Lepidoptera, superfamily Pyraloidea," in Arthropod fauna of the United Arab Emirates, Volume 1, Harten, A. van, Ed. Abu Dhabi: Dar Al Ummah Printing, Publishing, Distribution \& Advertising, 2008, pp. 469-561.

[13] J. De Prins and W. De Prins. "Afromoths, online database of Afrotropical moth species (Lepidoptera)," World Wide Web electronic publication (http://www.afromoths.net) [30.09.2020].

[14] A. Poltavsky, V. Kravchenko, M. Traore, S. Traore, P. Gergely, T. Witt, H. Sulak, R. Beck, A. Junnila, E. Revay, S. Doumbia, J. Beier, G. C. Müller, "The Pyraloidea (Lepidoptera) fauna of the woody savannah belt in Mali, West Africa," Zootaxa, vol. 4457 (1), pp. 39-69, 2018.

[15] H. Sutrisno, "Cladistic Analysis of the Australian Glyphodes Guenée and Allied Genera (Lepidoptera: Crambidae)," Entomological Science, vol. 5 (4), pp. 457-467, 2002.

[16] H. Sutrisno, "A Preliminary Study on Relationships among Selected Australian Members of the Tribe Spilomelini (Lepidoptera: Crambidae: Pyraustinae)," Zoological Science, vol. 19 (8), pp. 915-929, 2002.
[17] H. Sutrisno, "Phylogeny of Glyphodes Guenée (Lepidoptera: Crambidae: Spilomelinae) Based on Nucleotide Sequence Variation in a Mitochondrial CO I Gene: Congruence with Morphological Data," Treubia, vol. 33 (1), pp. 35-42, 2003.

[18] H. Sutrisno, N. Azuma, and S. Higashi, "Molecular Phylogeny of the Indo-Australian Glyphodes and its Allied Genera (InsectaL: epidoptera: Crambidae: Spilomelinae) Inferred from Mitochondrial COI and COII and Nuclear EF-1a Gene Sequences," Species Diversity, vol. 11, pp. 57-69, 2006.

[19] S. Park, J. Ko, S. Na, D. Lee, U. Bayarsaikhan, and Y. Bae, "Taxonomic Study of the Genus Glyphodes (Lepidoptera: Crambidae) from Laos," Korean Journal of Nature Conservation, vol. 10 (2), pp. 148-154, 2016.

[20] S. Rathikannu, and N. Chitra, "Genitalia study on the genus Glyphodes (Crambidae: Spilomelinae) in Tamil Nadu, India," Entomon, vol. 42 (2), pp. 145-152, 2017.

[21] G. Nagaharish, M. Shankara Murthy, A. Prabhuray, A. S. and S. G. S. Patil, "Faunistic studies on Crambidae: Pyraloidea (Lepidoptera) associated with fruit and flower crops of zone-1 and 2 of Karnataka, India," Journal of Entomology and Zoology Studies, vol. (1), pp. 875-880, 2017.

[22] P. M. Reddy and M. S. Murthy, "Taxonomic studies on the genus Glyphodes Guenee (Lepidoptera: Crambidae: Spilomelinae) from Karnataka, India," Entomon, vol. 44 (4), pp. 241-248, 2019.

[23] J. Gesquière, "Lépidoptères Microlépidoptères (deuxième partie)," Annales du Musée du Congo belge, Zoologie [3, Arthropodes], section 2, Catalogues raisonnés, vol. 7 (3), pp. 121-240, 1942.

[24] T. Walsingham and G. Hampson, "On moths collected at Aden and in Somaliland, "Proceedings of the Zoological Society of London, vol. 1896 (1), pp. 257-283, 1896.

[25] M. P. T. Gillet, "Brief notes on some species of micro-moths newly reported from Al Ain," Tribulus, vol. 7 (1), pp. 19-20, 1997.

[26] G. Robinson, "The Preparation of Slides of Lepidoptera Genitalia with Special Reference to the Microlepidoptera," Entomologist's Gazette, vol. 27, pp. 127-132, 1976.

[27] K. V. N. Maes, "A comparative morphological study of the adult Crambidae (Lepidoptera, Pyraloidea)," Proceedings and Annals of the Belgian Entomological Royal Society, vol. 131, pp. 383-434, 1995.

[28] J. C. Shaffer and E. Munroe, "Type Material of Two African Species of Herpetogramma and One of Pleuroptya (Lepidoptera: Crambidae: Pyraustinae)," Proceedings of the Entomological Society of Washington, vol. 91 (3), pp. 414-420, 1989.

[29] J. C. Shaffer and E. Munroe, "Type Material of Four African Species of Notarcha Meyrick, with Designation of Lectotypes and Changes in Synonymy," Proceedings of the Entomological Society of Washington, vol. 91 (2), pp. 248-256, 1989. 